\title{
De kontekstavhengige smertene
}

Artiklene om muskel- og skjelettlidelser i dette nummer av Tidsskriftet tyder på at det ikke er smerter, men fravær av smerter i muskel- og skjelettsystemet som er det unormale. Det slår meg under lesingen at kategorisering av tilstandene etter lokalisasjon og intensitet ikke kan være lett. Smertene kommer og går, og de fleste har smerter fra flere steder (1). Tankene går til Benninghoffs lærebok i anatomi, der han sammenliknet muskel- og skjelettsystemet med seilskuteriggens mast, stag og vanter: en liten skjevhet ett sted $\mathrm{i}$ dette systemet kunne påvirke helheten og gi skader og funksjonssvikt helt andre steder.

God diagnostikk er viktig for å utelukke alvorlige differensialdiagnoser, og iblant for valg av behandling. Men til tross for stor innsats på diagnostikkens område, er det i påfallende stor grad uspesifikk, symptomlindrende behandling som anbefales. Flere vektlegger også til syvende og sist nødvendigheten av en individualisert tilnærming. Når det allikevel ser ut til å være stor, for ikke å si for stor, interesse for bildediagnostikk, skyldes det kanskje at en spesifikk diagnose kan beskytte smertepasienten mot mistro og stigmatisering. Den som har bildefunn å vise til, kan til og med vedkjenne seg sine smertefrie perioder uten å bli stemplet som trygdemisbruker.

Artiklene peker hver på sin måte mot behovet for et videre perspektiv enn den tradisjonelle medisinske sykdomsmodellen med veldefinerte, lokaliserbare «sykdomsenheter» som responderer på spesifikk behandling. Smertene fortjener i større grad å bli forstått i den sammenhengen de opptrer, ikke bare som symptomer på en avgrenset kroppslig tilstand. Den som har smerter, reagerer med handlinger. Sosiologen Dorte Gannik har beskrevet hvordan ryggsmerter inngår i den mengden av ubehagelige symptomer som vi hele tiden opplever i hverdagen og som vi håndterer så godt vi kan (2). Bare unntaksvis betyr de alvorlig sykdom. Det meste går over av seg selv. Alternativt innretter vi oss så symptomene ikke forstyrrer oss i det vi holder på med, enten det er jobb eller familieliv - de to viktigste arenaene for hverdagsaktivitet. Ubehaget fører bare sjelden til legebesøk. Arbeidssituasjonen kan begrense mulighetene for å håndtere både ryggsmerter og andre plagsomme hverdagssymptomer (2). Alt avhenger av handlingsrommet vi har til å modifisere arbeidsvilkårene - redusere belastninger, ta en pause, variere arbeidsstilling, be om hjelp fra andre. Men også utenom arbeidslivet er handlingsrommet begrenset av slikt som økonomi, boligforhold og sosiale kontakter. Dorte Gannik bruker begrepet sykdomshandling (disease action) om alt individet gjør for å forstå sin sykdom og mestre symptomene. Hun mener dette er mekanismen som knytter levekår og sykdom sammen. Sykdomshandlingene begrenses og bestemmes av individets handlingsrom, som igjen bestemmes av sosialt skjevfordelte arbeids- og levekår. Smerter i muskel- og skjelettsystemet er i høy grad sosialt skjevfordelt, og mye av forskjellen kan forklares med ulike arbeidsforhold, slik som omfanget av fysiske jobbkrav og graden av innflytelse over egne arbeidsforhold (3). Kanskje det nettopp er denne pasientgruppens lave sosiale status og det store innslaget av kvinner som gjør det nødvendig for Kirsti Malterud å presisere at man må anerkjenne pasientens erfaringer (4). Det er samtidig en nyttig påminnelse om at det gamle idealet om at legen skal være pasientens advokat er verdt å forsvare i NAV-reformenes tid.
For hundre år siden var den industrialiserte verden opptatt av en epidemiaktig tilstand de kalte «industrial fatigue», karakterisert ved langvarig redusert arbeidsevne hos store arbeidergrupper, og spesielt blant kvinnelige arbeidere. Det ble nedsatt flere offentlige kommisjoner for å utrede tilstanden. «The British Association on Fatigue from the Economic Standpoint» beskrev i 1915 tilstanden som en «reduksjon av arbeidsevnen som følger av for mye arbeid eller mangel på hvile» (5). Våre dagers muskel- og skjelettlidelser er også blitt beskrevet som epidemiske og gjort til gjenstand for tallrike utredninger og kampanjer fra myndighetene. Symptomene skiller seg tilsynelatende fra «industrial fatigue» ved å være lokaliserte. Men kanskje er de ikke så lokaliserte allikevel, når de fleste faktisk har vondt flere steder? Fordelingen av muskel- og skjelettlidelser i befolkningen i dag, svarer til hvordan «industrial fatigue» var fordelt. Muskel- og skjelettsymptomene går også utover arbeidsevnen og de får ytterligere myndighetsinteresse fordi de medfører utgifter til sykelønn og uføretrygd. I en arbeidsmedisinsk lærebok fra vår tid kan vi lese en beskrivelse som har likhetstrekk med beskrivelsen av tilstanden hos sliterne blant de britiske industriarbeiderne: «Det formodes, at gentagne belastninger af vævsstrukturer, muligvis kombineret med mangelfuld restitution, er baggrunden for de arbejdsrelaterede lidelser i bevægeapparatet» (6).

Er det de samme fenomenene vi fortsatt studerer og utreder? Sammenhengen mellom yrkesarbeid og muskel- og skjelettsmerter har vært kjent i mange hundre år, men det som kan ha variert er hvordan plagene ble presentert. Det som for hundre år siden ble presentert for arbeidsgiver og fattighjelp som tap av arbeidsevne, presenteres kanskje nå som smerter. Fordi muligheten til å fritas for arbeidsplikt er større i vestlige land i dag enn for hundre år siden, vil også flere nå enn den gang komme frem med sine plager. Alternativet er å bli stemplet som arbeidssky eller å fortsette arbeidet. Både tretthet og smerter er velkjente symptomer på ubalanse mellom anstrengelse og hvile, eller mellom individuelle fysiske forutsetninger og kravene til ytelse. Problemene oppstår for alvor når man ikke har muligheter til å håndtere trettheten og smertene på en måte som forebygger kronisk skade. Når man ikke har handlingsrom, verken hjemme eller på jobb.

\section{Ebba Wergeland \\ ebba.wergeland@arbeidstilsynet.no}

Ebba Wergeland (f. 1946) er dr.med., spesialist i arbeidsmedisin og overlege i Arbeidstilsynet.

Oppgitte interessekonflikter: Ingen

Litteratur

1. Ihlebæk C, Brage S, Natvig B et al. Forekomst av muskel-og skjelettlidelser i Norge. Tidsskr Nor Legeforen 2010; 130: 2365-8.

2. Gannik D. Situational disease: elements of a social theory of disease based on a study of back trouble. Scand J Prim Health Care 2002; 20 (suppl 1): 25-30.

3. Mehlum IS. Work related health problems in the population. Doktoravhandling. Oslo: Institutt for helse og samfunn, Universitetet i Oslo, 2010.

4. Malterud K. Kroniske muskelsmerter kan forklares på mange måter. Tidsskr Nor Legeforen 2010; 130: 2356-9.

5. Vernon HM. Industrial fatigue and efficiency. London: Routledge and Sons, 1921: , 1 6. Andersen JH. Arbejdsrelaterede lidelser i bevægelseapparatet. I: Autrup H, Bonde JP, Rasmussen K et al, red. Miljø og arbejdsmedisin. København: FDLs forlag, 2000. 